\title{
Impact of democratic politics on caste with special reference to the Patnis of Cachar
}

\author{
Satyajit Das ${ }^{1}$ \\ ${ }^{1}$ Research Scholar, Depatment of Political Science, Assam University, Silchar-11, Assam.
}

\begin{abstract}
The nature of interaction between caste and politics has taken veriety of forms in different parts of India. This phenomenon is also studied widely. These studies have moved away from doctrinaire positions like, is caste disappearing? Instead these studies have focused on transformation in caste structure due to the impact of democracy and changes in politics due to its interaction with caste changes in caste and politics do very often place to place. The traditional structure of caste responded to changes in its political and economic environment by transforming from below and within. Hierarchy, privilege and moral parochialism no longer exhaust its secular significance. Caste has become a means to level the old order's inequalities by helping to destroy its moral basis and social structure. It contribute to the success of political democracy by helping India's mass electorate to participate meaningfully and effectively in it.
\end{abstract}

Key words: Caste, democracy, hieraechy, parochialism and transformation.

\section{Introduction}

The confrontation in India between the age-old caste system and the parliaentary democracy based on universal suffrage vividly illustrates the manner in which old and historical societies get involved in and provide content to the modernizing process. The adoption of modern representative democracy and the extension of universal adult franchise made it possible for scheduled castes to realize their importance in electoral politics. This realization led to heighten assertion of Dalits in both social and political spheres. Thinking of caste and politics, it may be noted that caste societies have witnessed simultaneously an increase in caste consciousness and bellicosity under the impact of modern representative democracy. Though it is not possible to eliminate the caste system entirely from the Indian society but a dramatic upsurge in the political participation of hitherto marginalized caste groups is leading to gradual erosion of its rigidity and symbols rooted in the tradition. The caste system in India is marked by the class division, hereditary occupation, marriage within caste, food regulations and untouchability. But the condition of scheduled castes in Assam is significantly different from other parts of India. Caste system is not rigid like other parts of India and untouchability is not very rampant. Scheduled castes have not taken to agitations and protests like other parts of India which may be due to stagnant economic situation and limited political avenues.

In the process of change, normative basis of traditional hierarchical social system alters significantly and as a consequence social attitudes also change. New understanding alters the attitudes of members. They think in new terms like denial of ritual inferiority, the ability to control their lives etc. These changes occur due to improvement in economic status of some members of the community. In other words, emerging economic class challenge traditional normative basis of caste system and attempt to constitute new social order in which the caste may occupy significant place. In this reconstitution politics is an important resource. As the conduct of politics moves from the village level to state capital political perceptions motives and organizations become more differentiated independent and powerful.[1] Horizontal solidarities and interests latent in the caste system have been used in its structural, functional, and cultural transformation.

\section{Political party as an agent of social change}

Modern politics helped to dissolve caste based social hierarchy and contributed to the success of political democracy. A political party is the cornerstone of representative democracy. In its quest for capturing political power, political parties transform social order by recruiting members from all quarters of society. "Politics is a competitive enterprise, its purpose is the acquisition of power for the realization of certain goals, and its process is one of identifying and manipulating existing and emerging allegiances in order to mobilize and consolidate positions. The important thing is organization and articulation of support..........".[2] Political

\footnotetext{
${ }^{1}$ Rudolph and Rudolph, The Modernity of Tradition, Political Development in India, Orient Longman, Hyderabad, $1969, \mathrm{p}-81$. ${ }^{2}$ Rajni kothari, Introduction: Caste in Indian Politics, in Rajni Kothari (ed.) Caste in Indian Politics, Orient Longman Limited, Hyderabad, 1995, p-4.
} 
parties in the quest for numerical strength split, combine, or fuse castes of all ranks when upper caste may require lower caste support for numerical strength and lower caste may support upper caste leadership for access to resources and opportunities or for interest to secure access to political power through parties that challenge established norms and structures.

\section{Review of related literature}

It will be useful to study literature relating to caste and politics. It will be irrelevant to ask a question like is caste disappearing? No social institution disappears just like that. It would be more interesting to ask: what form is caste taking under the impact of modern politics and what form politics is taking in a caste oriented society." Politics is viewed a competitive enterprise, its purpose is the acquisition of power for the realization of certain goals and its process is one of identifying and manipulating existing and emerging allegiances in order to mobilize and consolidate positions.

Easton defines politics as authoritative allocation of values. That is how, politics mobilizes various existing allegiances in order to attain certain goals. The crucial connecting link between caste and political system is political party, association or movement. A political party consists of those whose entrepreneurial activities are essentially devoted to the recruitment of followers who attempt to modify the system either by participation in government or by directing their action against it.[3]

By prescribing rules governing the recruitment of members, selection of leaders and the intra-party relationships which emphasize the universal functionally specific and achievement oriented criteria of organization and distribution of power, the party makes available to the people forms of behaviour, which are usually opposed to those inherent in traditional social stratification system.

Thus politics, a modern enterprise, provide a different set of values to hierarchical caste system. It would be interesting to see how politics based on modern values would transform a particular caste or concept.

\section{Importance and objective of the study}

This study assumes significance for many reasons. The study of scheduled caste has emerged as an important field of study due to variety of factors. This has been due to growing public interest in protesting atrocities and humiliations on scheduled castes, increase in Dalit mobilizations across the country, rise of BSP and other political parties with the support of scheduled castes etc. There exist significant studies in this area. But academic attention to scheduled castes in North-East-India is minimal as other big issues like ethnic conflicts dominate the canvass. In view of the above, the propose study seeks is to capture the process of change in social and political attitudes of a scheduled caste community, Patnis, by looking at the perceptions of political elite of the community. The choice of Patni community is purely for empirical reasons. This community is significant because it is numerically large among scheduled caste communities. There have been Patni MLA and MP's in different constituencies of Cachar which reveals their prominence in social and political affairs.

\section{Methodology and Data}

Cachar district covers fifteen development blocks and out of them six has been selected through purposive sampling. The main aim of using purposive sampling was to include those blocks where Patnis are influential politically and numerically large in number. These development blocks are Katigorah, Narshingpur, Palonghat, Salchapra, Silchar and Sonai. This study is an attempt to capture the perceptions of the political elite of Patni Community as they operate with certain vision, goals and values which transform nature of caste. The term political elite include the comprising members of both Block or Mandal committees of both Indian National Congress and Bharatiya Janata Party. The list of members of Block level committees are collected from party offices. Five members of Congress Party and four members of Bharatiya Janata Party are interviewed in each of the selected blocks. Thus, the total sample size is fifty four.

\section{Patnis in Cachar}

The Patni community is one among the sixteen scheduled caste communities of Assam. The people of this community are predominantly the inhabitants of three bengali dominated districts i.e., Cachar, Karimganj and Hailakandi of Assam. It accounts for 8.3 per cent of scheduled caste population in Assam. According to the census of 1971, Patni population in Barak Valley was 85,910. According to the same authority, Patnis constitute the highest member of scheduled caste population in Cachar. "The Patnis are mainly a land owning community and the landholdings are individually owned. Traditionally, their primary occupation is cultivation; fishing is only a subsidiary occupation.”[4] They profess Hindu religion. Guswami Brahmins provide priesthood to the

${ }^{3}$ David E. Apter, A Competitive Method for the Study of Politics in Harry Eckstein and David E. Apter (ed.), Comperative Politics: A Reader, the Free Press, Glencoe: 1962, p-83.

${ }^{4}$ Singh K.S., The Scheduled Castes, Vol-1, Anthropological Survey of India, Oxford University Press, Delhi, 1998, p-1086. 
Patins strictly according to the injunctions of Hindu Shastras.[5] The Patnis however, claim to be the offsprings of Madhava who ferried Rama across river Yumana on his way from Ayodhya to Mithila. There are certain special surnames found among Patni people such as, Roy, Sarkar, Sikdar, Das, Mazumder, Biswas, Laskar, Borbhuiya, Purkayastha etc. Many of their anecstors for their good services under the ruling princes of Cachar won various titles such as, Laskar, Barbhuiya, Mazumder, Purkayastha, Roy, Sarkar, Sikder, Biswas etc. [6] The call of late Nibaran Chandra Laskar to Kacharis including Patnis to stand behind Congress in its fight for the freedom of the country rewarded him and in 1946, he became MLA and member of Constituent Assembly of India. During 1952 to 1961, he was a Member of Parliament and resigned his seat as protest against police firing in language movement or Vasha Andolon. In 1961, his son Mr. Nihar Ranjan Laskar became state union minister and also the health and home affairs during 1982-87. During 1991 and 1996 election Dwarika Nath Das a BJP candidate from Patni community was elected from the Karimganj Parliamentary constituency. However, most of the members represented legislative assembly from Patni communities in Assam were affiliated to Congress party. Late Romesh Chandra Das of Congress was elected as member of Legislative Assembly from Karimganj in the year 1946, Mr. Jatindra Barbhuiya from Sonai perhaps in 1946, Mr. Digendra Chandra Purkayastha from Dholai in 1977, Mr. Lilamoy Das from Ratabari in 1977, Mr. Shubal Das from Ratabari in 1982.[7]

\section{Significance of caste in public realm}

There have been opinions among the public that caste is not the criteria in dealings in public affairs. What matters is money and worth or talents. This is what normal secularization process entails. Here, it is attempted to find out the views of Patni political elite. The responses of the elite might help us to have an understanding of their views on the current process of secularization. The perceptions of the elite show that 56 per cent of elite have expressed positive opinion indicating satisfaction with the pace of secularization and 44 per cent are not happy with it. (Table-1)

The responses of the elite are shown on the basis of their party affiliations (Table-2). Here, the responses elicit seems to be more clear, the members of BJP are dissatisfied with the rate of secularization process while the members of INC are almost equally divided on this. Among the members of INC 53 per cent expressed positive opinion and 47 per cent have expressed negative opinion. While 35 per cent members of BJP have positive opinion and 65 per cent have expressed negative opinion. It implies that the members of BJP are more dissatisfied with the rate of secularization.

Table: 1 Patnis accepting the process of secularization

\begin{tabular}{|l|l|l|l|}
\hline & \multicolumn{1}{|c|}{ Yes } & No & Total \\
\hline Elite & $30(55.56)$ & $24(44.44)$ & $54(100.00)$ \\
\hline
\end{tabular}

Table: 2 Party wise perception about significance of caste in public realm

\begin{tabular}{|l|l|l|l|}
\hline Elite & Positive & Negative & Total \\
\hline INC & $16(53.33)$ & $14(46.67)$ & $30(100.00)$ \\
\hline BJP & $8(34.78)$ & $16(65.22)$ & $24(100.00)$ \\
\hline
\end{tabular}

\section{Traditional ritual status}

The question of ritual status of a caste in the eyes of its members is of significance because it indicates one's place in caste society. It may be mentioned that among the lower caste groups there has been a tendency to rise higher in social status by adopting the rituals of high castes. It is mostly because of their belief that they were not lower in social ladder in the traditional society and enjoyed superior status. This encourages them to claim higher social position and positive self identity. It has been argued by political sociologists that caste has been losing its traditional functions and assuming new function like consolidation of community under conditions of democracy. Here, the interesting question would be what the nature of claims of ritual status is. Thus, it would be interesting to find out the traditional status of Patnis through their own perceptions.

The issue is included because Patnis claim themselves as Kshatriyas and wear sacred thread. These questions have been asked not to find out the truth status of these claims, but to capture changing social perceptions of what they are and their self worth. Elite almost unanimously accepted that they are ritually not inferior and are not of lower birth. (Table-3) 91 per cent of them has expressed the opinion that their traditional social worth is not of inferior kind and deserves treatment like Kshatriyas. This is not to establish the truth of the claims but to

\footnotetext{
${ }^{5}$ Harprashad Das, Halik Patni ba Mahishyagonar Itibrittya, Mukherjee Press, Culcutta, 1940, p-101.

${ }^{6}$ Bimal J. Deb and Dilip K. Lahiri, Cosmogony of Caste and Social Mobility in Assam, Mittal Publications, Delhi, 1984, p-47.

${ }^{7}$ Lakhimohan Das, Patni Janagosthir Ruprekha, Srimati Niyati Das, Lumding, 1996, p-129.
} 
understand dynamic social perceptions. Even under conditions of modern democracy they claim superior worth from pure origins of their caste where they bank upon the resources of tradition.

The responses of the elite are shown on the basis of party affiliations (Table-4). Here also the responses elicit same trend. Elite on the basis of their party affiliation do not admit any variation in their opinion. The elite irrespective of their party belonging have expressed positive opinion about traditional ritual status of their community. Among the members of INC 93 per cent expressed positive opinion and 87 per cent BJP members have same opinion. Thus, it may be mentioned that there is no difference of opinion across classes and party affiliation. The elite of the community have projected their higher ritual status irrespective of differences in economic status and party affiliation.

Table 3. Traditionally, Patnis are not of inferior ritual status

\begin{tabular}{|l|l|l|l|}
\hline & Yes & No & Total \\
\hline Elite & $49(90.75)$ & $5(9.25)$ & $54(100.00)$ \\
\hline
\end{tabular}

Table 4. Party wise perception of traditional inferior ritual status

\begin{tabular}{|l|l|l|l|}
\hline Elite & \multicolumn{1}{|c|}{ Positive } & Negative & Total \\
\hline INC & $28(93.33)$ & $2(6.67)$ & $30(100.00)$ \\
\hline BJP & $21(87.5)$ & $3(12.5)$ & $24(100.00)$ \\
\hline
\end{tabular}

\section{Social Status}

Social status in relation to a caste implies the social position of the particular caste in comparison to other castes living in the neighborhood and the socio-economic condition of a caste in a social hierarchy. In a village or in a number of villages or in a specific area, several caste groups are found with their expertise in a particular profession. This profession actually determined the social status of a community in the traditional social system. Each caste group with its caste occupation acquired specific position in the status hierarchy. In the previous section, most of them agree that they are not of inferior kind ritually speaking. In this section, questions indicating opposing positions also receive positive response. It may be because two different ways of posing questions draw responses from two different cultural registers available in public. A careful distinction should be made between ritual position and social hierarchy. Perhaps questions with similar content, if they have been posed in a different manner, the responses vary to a significant extent.

Elite of Patni community are requested to express their opinion about low ranking of the community in social ladder. The data shows that Patni political elite have accepted that they rank low in social hierarchy as 93 per cent of them hold this opinion. It indicates that the leadership in the community is assertive towards their community. (Table-5)

Again if responses are analyzed on the basis of their party affiliation (Table-6), it is found that irrespective of party affiliation, the elite of the community expressed negative opinion about their community. They consider this community as one of the communities which ranked low in social hierarchy. It might be because they respond from different registers when similar questions were asked with different leads. They believe that they are ritually pure within the social world of tradition and think that they rank low in social order when it comes to state and political democracy. They claim latter position to be relevant players in democracy because democracy understands the language of deprivation much better.

Table 5. Patni community is one among the communities that ranked low in social ladder

\begin{tabular}{|l|l|l|l|}
\hline & Yes & No & Total \\
\hline Elite & $50(92.59)$ & $4(7.41)$ & $54(100.00)$ \\
\hline
\end{tabular}

Table 6. Party wise perception of ranking low in social status of the community

\begin{tabular}{|l|l|l|l|}
\hline Elite & Positive & Negative & Total \\
\hline INC & $29(96.67)$ & $1(3.33)$ & $30(100.00)$ \\
\hline BJP & $21(87.5)$ & $3(12.5)$ & $24(100.00)$ \\
\hline
\end{tabular}

\section{Practice of untouchability}

Among Shudra castes there are two categories excluded or impure and not excluded or pure. The excluded or impure are considered as untouchables. Laskar mentioned about the restriction in the field of 
Temple entry, inter dining and acceptance of cooked food from an untouchable caste ${ }^{8}$. But at present, there have been some changes in the traditional social system due to modernization and the impact of democracy. The social status of an individual is supposed to be determined more by his achievements and not by his caste. It is the acquisition of the wealth, status of education, occupation and political power etc. that determines one's social status. Patni community is a scheduled caste community thereof; it would be interesting to know the self perception of political elite of Patni community regarding the practice of untouchability. Thus, to see the perception of elite of the Patni community about the practice of untouchability, this issue is important.

The responses (Table-7) show that the elite of the community supported the fact that traditionally Brahmins did not accept water from the Patnis hand. It implies that untouchability in some form was present in the social life of Cachar. And while interviewing the elite of the community some of them also mentioned that the people of this community faced the problem of untouchability in Cachar. However, 22 per cent of respondents admit that there was no practice of untouchability.

The responses of the elite were also evaluated on the basis of their party affiliations (table-8). Here, elite of the community also admitted the practice of untouchability. But a handful of members from the INC seem to be denying the practice of it and the members of BJP are acknowledging the practice of untouchability. Among the members of Congress party, 73 per cent and 83 per cent of BJP members admit that untouchability in some form was present in the social system in Cachar. But 27 per cent members of INC and 17 per cent of BJP members did not admit the practice of untouchability.

Table 7. Traditionally, Brahmins do not take water from the hands of Patnis

\begin{tabular}{|l|l|l|l|}
\hline & Yes & No & Total \\
\hline Elite & $42(77.77)$ & $12(22.23)$ & $54(100.00)$ \\
\hline
\end{tabular}

Table 8. Party wise perception of practice of untouchability

\begin{tabular}{|l|l|l|l|}
\hline Elite & Positive & Negative & Total \\
\hline INC & $22(73.33)$ & $8(26.67)$ & $30(100.00)$ \\
\hline BJP & $20(83.33)$ & $4(16.67)$ & $24(100.00)$ \\
\hline
\end{tabular}

\section{Conclusion}

After a close look on the perceptions of political elite of the Patni community about pace of secularization, ritual status, position in social hierarchy and practice of untouchability in Cachar district, a specific trend towards emerging new social attitudes is found on some issues. All of them agree on one issue that Patnis are ritually impure and they ranked low in social order. On the issue of process of secularization in public realm, significant number of them agrees that it is not caste but money or talent is valued in public. And a majority of the BJP members among the elite also endorse this view. Majority of the elite agree that untouchability in the form of not accepting water from Patnis is still practiced. Thus, Patni elite hold social attitudes undermining the traditional social order which enhances their self-worth and value of the community in social order. The elite who hold such views, prefer BJP in politics and who express social attitudes in tune with normative understanding of caste, they support Congress party.

\section{References}

[1] LIoyd I. Rodolph, and Susanne Hoeber Rodolph, The modernity of tradition political development in India (Orient Longman Limited, Hyderabad, 1961).

[2] Rajni kothari, Introduction, in Rajni Kothari (ed.), Caste in Indian politics, (Orient Longman Limited, Hyderabad, 1995).

[3] David E. Apter, A competitive method for the study of politics in Eckstein, Harry and David E. Apter (ed.), Comparative politics: a reader, (Free Press, Glencoe, 1962),

[4] K.S. Singh, The scheduled castes, anthropological survey of India (Oxford University Press, Delhi, Vol-1., 1998).

[5] Harprashad Das, Halik patni ba mahishyagonar itibrittya (Mukherjee Press, Calcutta, 1940)

[6] Bimal J. Deb and Dilip K. Lahiri, Cosmogony of caste and social mobility in Assam, (Mittal Publications, Delhi, 1984).

[7] Lakhimohan Das, Patni janagosthir ruprekha (Srimati Niyati Das, Lumding, 1996).

[8] N.R. Laskar, Backward communities in Assam: A study of the scheduled castes with particular reference to surma valley (1919. 1947), (Phd thesis, Department of History, Guwahati University, Assam, 2001.

\footnotetext{
${ }^{8}$ Nitish Ranjan Laskar (2001), Backward Communities in Assam: A study of the Scheduled Castes with Particular Reference to Surma Valley (1919-1947) Department of History, Guwahati University, p-96.
} 